

Közzététel: 2020. július 24.

A tanulmány címe:

A megújuló forrásból származó villamos energia önellátási és exportlehetőségei a

Szerző: magyarországi településeken

Kulcsár Balázs

https://doi.org/10.15196/TS600401

Az alábbi feltételek érvényesek minden, a Központi Statisztikai Hivatal (a továbbiakban: KSH) Területi Statisztika c. folyóiratában (a továbbiakban: Folyóirat) megjelenó tanulmányra. Felhasználó a tanulmány, vagy annak részei felhasználásával egyidejüleg tudomásul veszi a jelen dokumentumban foglalt felhasználási feltételeket, és azokat magára nézve kötelezónek fogadja el. Tudomásul veszi, hogy a jelen feltételek megszegéséböl eredö valamennyi kárért felelösséggel tartozik.

1) A jogszabályi tartalom kivételével a tanulmányok a szerzői jogról szóló 1999. évi LXXVI. törvény (Szjt.) szerint szerzői műnek minősülnek. A szerzői jog jogosultja a KSH.

2) A KSH földrajzi és időbeli korlátozás nélküli, nem kizárólagos, nem átadható, térítésmentes felhasználási jogot biztosít a Felhasználó részére a tanulmány vonatkozásában.

3) A felhasználási jog keretében a Felhasználó jogosult a tanulmány:

a) oktatási és kutatási célú felhasználására (nyilvánosságra hozatalára és továbbítására a

4. pontban foglalt kivétellel) a Folyóirat és a szerző(k) feltüntetésével;

b) tartalmáról összefoglaló készítésére az írott és az elektronikus médiában a Folyóirat és a szerző(k) feltüntetésével;

c) részletének idézésére - az átvevő mű jellege és célja által indokolt terjedelemben és az eredetihez híven - a forrás, valamint az ott megjelölt szerző(k) megnevezésével.

4) A Felhasználó nem jogosult a tanulmány továbbértékesítésére, haszonszerzési célú felhasználására. Ez a korlátozás nem érinti a tanulmány felhasználásával előállított, de az Szjt. szerint önálló szerzői műnek minősülő mű ilyen célú felhasználását.

5) A tanulmány átdolgozása, újra publikálása tilos.

6) A 3. a)-c.) pontban foglaltak alapján a Folyóiratot és a szerző(ke)t az alábbiak szerint kell feltüntetni:

„Forrás: Területi Statisztika c. folyóirat 60. évfolyam 4. számában megjelent, Kulcsár Balázs által irt, A megújuló forrásból származó villamos energia önellátási és exportlehetöségei a magyarországi településeken c. tanulmány"

7) A Folyóiratban megjelenő tanulmányok kutatói véleményeket tükröznek, amelyek nem esnek szükségképpen egybe a KSH, vagy a szerzők által képviselt intézmények hivatalos álláspontjával. 


\section{A megújuló forrásból származó villamos energia önellátási és exportlehetőségei a magyarországi településeken}

\section{The prospects of electricity self-sufficiency deriving from renewable sources and energy export in the Hungarian settlement stock}

Kulcsár, Balázs

Debreceni Egyetem Műszaki Kar E-mail:kulcsarb@eng.unideb.hu
A tanulmány célja - szoftveres kalkulációval és közepes kihasználtsági adatok alapján olyan becslési módszer kidolgozása, amellyel megállapítható, hogy a leginkább decentralizált elhelyezkedésûnek és helyinek tekinthetô, a legkisebb erőmû́-kategóriába tartozó, megújuló energiaforrást hasznosító, háztartási méretú kiserőmúvek (HMKE) és a 0,5 MW alatti beépített teljesítményú - nem engedélyköteles, nem HMKE - kiserőmúvek milyen arányban járulnak hozzá a települések villamosenergia-igényének biztosításához, Magyarország összes települése vonatkozásában. A szerző - a gazdasági környezet és a támogatási háttér változásainak figyelembevételével - bemutatja az erőművek létesítését lehetővé tevő törvényi feltételek rendelkezésre állása óta eltelt tíz év alatt az energiaváltás folyamatában elért eredményeket. Választ keres arra kérdésre, hogy léteznek-e hazánkban olyan települések, amelyek képesek villamosenergia-igényüket 100\%-ban, helyi megújuló forrásból kielégíteni, sôt esetleg túltermelni, ami energiaexport-lehetőséget teremthet a környező települések irányába. E vizsgálat rávilágíthat arra, hogy Magyarországon elméletileg megvalósíthatók a decentralizált, helyi, megújuló forrást hasznosító energiaellátó rendszerek. A szerző által energia-földrajzi és településföldrajzi szempontok alapján kidolgozott módszer alkalmazásával a jövőben pontosabban tervezhetôvé válhat az energiapolitika, korrigálható a támogatási rendszer, módosítható az energiamix, valamint gyorsítható az energiaváltás folyamata. 
The goal of the study is to develop an estimation method with software calculation, based on average exploitage data. With this calculation we will determine what proportion the small-scale household power plants (SSHPP) and a power plant under 0.5 MW capacity contribute to the electricity demand of all Hungarian settlements. These small power plants generate electricity only from local renewable energy sources.

Furthermore, this study would like to present the results achieved in the past 10 years since the Electricity Act came into force which allows the installation of small power plants. It would like to show the results obtained in the process of energy sources renewal.

Are there any settlements in Hungary which could provide their electricity demand from local renewable energy sources in 100\% and could they even overproduce it?

If the results prove overproduction this may create an opportunity for energy export to the neighbouring settlements.

This study points out that decentralized, local, renewable energy-based power supply systems theoretically may be realised in

Keywords: Hungary.

self-sufficient settlements, Whit this method, energy policy could be energy export, decentralized energy production, more easily planned, the support system could be revised, the energy mix could be renewable energy, energy geography, modified and the process of energy renewal may be accelerated.

Hungary settlement geographical viewpoints.

Beküldve: 2019. szeptember 23.

Elfogadva: 2020. február 20. 


\section{Bevezetés}

Az energiafelhasználás átállítása megújuló energiaforrásokra (, az energiaváltás) egyre sürgetôbb globális feladat, és végrehajtásának szükségességét széles körú, egyre borúlátóbb klímakutatási eredmények támasztják alá, továbbá a velük kapcsolatos aggodalmakat a globális energiafelhasználás jövőbeli növekedési prognózisa is indokolja (Sebestyénné Szép-Tóth 2019). E kockázatok csökkentése érdekében az energiaváltást a villamosenergia-, a hő- és a közlekedésienergia-szektorban egyaránt meg kell valósítani.

Magyarország energiamérlegében ma még jelentős részt tesznek ki a fosszilis energiahordozók, amelyek többsége importtal biztosított. Tehát fontos cél a megújuló energiaforrások arányának növelése a hazai energiamixben. Magyarországon viszonylag későn kezdődött az energiaváltás folyamata, azonban az elmúlt tíz évben jelentős eredményeket sikerült elérni, elsősorban a villamosenergia-termelés karbonsemlegessé tételében (MAVIR 2017). Európai szinten azonban e téren jelentôs a lemaradás (Eurostat 2004-2017).

A megújuló energiaforrások viharos gyorsaságú és világméretű terjedése során egyre több település tűzi ki célul energiaigényének megújuló forrásokból történő kielégítését. Az energia többségét a településeken használják fel, nyilvánvalóan a szállitási veszteségek és az ebből származó környezeti terhelés elkerülése érdekében (Málek et al. 2018) a leggazdaságosabb, a legkíméletesebb és az energiabiztonság szavatolása érdekében a legkézenfekvőbb eljárás az energia helyi, decentralizált megtermelése, megújuló energiaforrásokból (Sáfián-Munkácsy 2015, Flavin 1988, Hayes 1982, Szuppinger 2000). Nem minden település alkalmas és képes annyi megújuló forrásból származó villamos energiát termelni, amennyi a saját ellátásához szükséges. A terület adottságaitól függően ez nem is feltétlenül szükséges, amennyiben a településegyüttes vagy kistérség egyes települései megtermelik a közösség energiaszükségletét (Capellán-Pérez et al. 2020, Koncz-Nagyné Demeter 2015). Ennek ellenére a települési szintű, megújuló forrásból származó villamosenergia-önellátás megvalósításának lehetőségeivel és az eredmények mérésével kevés kutatás, valamint szervezet foglalkozik.

A tanulmány célja a következők vizsgálata:

- A leginkább decentralizált elhelyezkedésűnek és helyinek tekinthető legkisebb erőmű-kategóriába tartozó, megújuló energiaforrást hasznosító, háztartási méretú kiserőmúvek (HMKE) és a 0,5 MW alatti beépített teljesítőképességú, nem engedélyköteles, nem HMKE kiserőmúvek (továbbiakban 0,5 MW alatti kiserőművek) milyen arányban járulnak hozzá a települések villamosenergiaigényének biztositásához, Magyarország összes települése vonatkozásában.

- Az erőművek létesítését lehetôvé tevő törvényi feltételek rendelkezésre állása óta eltelt tíz év alatt - a gazdasági környezet és támogatási háttér változásainak figyelembevételével - milyen eredmények születtek az energiaváltás folyamatában.

Területi Statisztika, 2020, 60(4): 399-424; DOI: 10.15196/TS600401 
- Léteznek-e Magyarországon olyan települések, amelyek képesek villamosenergia-igényüket 100\%-ban helyi megújuló forrásból kielégíteni, és az esetlegesen túltermelő települések mekkora helyi térséget képesek ellátni, tehát az energiaváltás megvalósítható-e.

A szakirodalom szerint van relevanciája a települési szintú villamosenergiaönellátásnak, amire egy-egy település esetében példát is találhatunk, azonban egy egész ország településállományára vonatkozóan ezt még nem mérték fel.

\section{Elözmények}

A téma relevanciájának alátámasztása érdekében áttekintjük a települési energiaönellátás útját, a szakirodalom megállapításait, a nemzetközi szervezetek adatgyújtési, értékelési módszereit, valamint a kutatóintézetek és közösségi kezdeményezések meghatározásait.

A megújuló energiaforrások hasznosítására széleskörűen az 1973-as olajválság irányította rá a figyelmet, egyéb más változatok mérlegelése közben. Ezt követően, az energiaigények 100\%-ának megújuló forrásból történő fedezése nemzeti szinten már 1975-ben felmerült Dánia esetében (Sørensen 1975), majd ezt további elméletek (Lovins 1976) és szoftveres modellek követték világszerte (Lund 2006). A tudományos elméleteken túlmenő első konkrét lépéseket Izland tette meg 1998-ban, amikor is kormányzati döntést hoztak az energiaváltásról. A települési önellátórendszerek kialakulásának kezdete a németországi megújuló energiáról szóló törvény 1997-es hatálybalépéséhez köthető, amely a megtérülés kiszámítását is lehetővé tette (EEG 2000-2017). A Stern-jelentés (2006) újabb áttörést hozott a megújuló energia megitélésében, amely a környezetvédelmi és technológiai érveken túlmenően ökonómiai téren is hitelesen támogatta meg az energiaváltás kényszerú és ésszerű követelményét (Stern 2006). Magyarországon az első számítógépes modellezés az Eötvös Loránd Tudományegyetem (ELTE) Környezet- és Tájföldrajzi Tanszékén készült (Munkácsy 2011). Az energiaváltás melletti kormányzati kötelezettségvállalások eddigi legmagasabb szintjén a „Marakesh Vision” áll, amelyben több - a klímaváltozás negatív hatásainak leginkább kitett - állam vállalta energiarendszerének megújuló alapokra helyezését (UN 2016).

\section{Az első önellátó települések}

Települési szinten az egyik legkorábbi példa a bajorországi Wildpoldsried település volt, ahol a németországi megújuló energiáról szóló törvény (EEG 2000-2017) megszületését követôen a település célul tűzte teljes - villamos, hő és közlekedési - energiaellátásának megújuló forrásokra történő helyezését, a helyben elérhető erőforrásokra támaszkodva (Rajgor 2012). Az elsô sikeres, elsősorban német (Aller-LeineTal, Effelter, Alzey-Land régió, Bruchsmühlbach-Miesau, Dardesheim, Großbardorf), dán (Samsø-sziget, Frederikshavn) és osztrák (Güssing) települési 
példákat követően, többek között Wen Li és szerzőtársai (2013) németországi esettanulmányokban foglalkoztak a közösségi tulajdonban lévő megújuló energiához kapcsolódó projektek végrehajtásának sikeres társadalmi, szociológiai tényezőivel. Az első jó gyakorlatokat további települések követték a falvaktól a nagyvárosokig (Energie Region - Aller-Leine-Tal, Bioenergiedorf-Effelter, Alzey-Land régió, 100ee Erneuerbare Energie Region, Güssing Renewable Energy, Dardesheim Renewable Energy Projects, FWR Energie Genossenschaft - Großbardorf, Sierra Club - Ready for $100 \%)$.

\section{Szakirodalmi források}

A szakirodalom a villamosenergia-ellátás terén önellátó települések tekintetében elsősorban az elektromos hálózaton kívüli, rurális térségek, szigetek villamosenergiaellátásának 100\%-os biztosítására keres tisztán megújuló energián alapuló, illetve hibridmegoldásokat (Ashok 2007, Goodbody et al. 2013). Duić és Carvalho (2004), valamint Uyar és Beşikci (2017) pedig e földrajzi térségek önellátásának megvalósítása és a rendszerkiegyenlítés érdekében a helyi megújuló forrásból származó villamos energia tárolására hidrogén elóállitását javasolták. Hasonlóan a megújuló energiából elóállított villamos energia tárolásának megoldásait vizsgálták India esetében Neves és szerzőtársai (2014), valamint Rahman és szerzőtársai (2016) Kanada esetében a hálózaton kívüli, rurális térségek esettanulmányain keresztül.

\section{Nemzetközi energetikai szervezetek}

Számos energetikai szervezet múködik a világon, amely globális és regionális szinten vizsgálja az energiarendszert, követi a trendeket, prognózisokat és szcenáriókat alkot annak jövőbeli alakulásáról, benne a megújuló energiaforrások szerepéról (International Energy Agency - IEA, World Energy Council, International Renewable Energy Agency - IRENA, European Renewable Energies Federation - EREF, European Renewable Energy Council - EREC, Bloomberg New Energy Finance, Bundesverband Erneuerbare Energie e.V. BEE, U.S. Energy Information Administration - EIA). A felsorolt szervezetek globális, regionális és nemzeti szinten figyelik a megújuló energiaforrások előretörését, valamint az energiaváltás megvalósítási esélyeit és a cél elérésének lehetséges időpontjait. E szervezetek ugyanakkor - a rendelkezésükre álló óriási adatbázisok ellenére - települési szinten nem végeznek értékeléseket.

\section{Kutatóintézetek, civil szervezetek és közösségi kezdeményezések}

Az energiaváltás települési léptékú megvalósításával a hivatalos szervezetek helyett inkább kutatóintézetek, közösségi kezdeményezések és civil szervezetek foglalkoznak, akik egységbe szervezik és támogatják a 100\%-ban megújuló forrásból elóállí-

Területi Statisztika, 2020, 60(4): 399-424; DOI: 10.15196/TS600401 
tott energia használatára való áttérést. Globális hálózatot hoznak létre a teljes energiaváltás támogatói között, szervezik a nemzeti, regionális és települési szintủ kezdeményezéseket. A 100\%-ban megújuló forrásból hasznosított energia elérésének módját azonban nem határozzák meg (The Global 100\%, Go 100\% renewable energy, Institute for Local Self-Reliance - ILSR, Sierra Club - Ready for 100\%, 100\% RES communities, Energiaklub Szakpolitikai Intézet Módszertani Központ).

\section{Adatok és módszerek}

Az említett szakirodalmi források által használt és az esettanulmányokban megállapított módszertant korábbi (Kulcsár 2018) tanulmányunkban már részletesen elemeztük. A szakirodalom, a hivatalos energetikai szervezetek, kutatóintézetek, a megújuló energiát támogató civil szervezetek és a közösségi kezdeményezések az eltérô földrajzi léptékú térségek megújuló forrásból történô energiaellátására vonatkozóan nem határozzák meg a 100\%-os arány teljesítésének kritériumait. A cél, a helyi megújuló energiaforrások hasznosításával, megújuló forrásból előállított importenergia vásárlásával, energiacserével vagy energiakompenzációval, valamint a település területén külső befektetői forrásból létesített nagyerőművekkel is teljesíthető. A hazai településállomány önellátottsági szintjének meghatározásakor figyelembe vettük a helyi forrásokat, mellyel egyrészt a település szigorúan vett területén megtalálható megújuló energiaforrásokat vettük számításba, ezen keresztül a település energiatermeló képességeit, másrészt ez a módszer a decentralizált energiatermelés kritériumainak is megfelelt. A települési arányok torzulásának elkerülése érdekében a megújuló energiával múködő nagyerőmúveket nem vettük figyelembe ( $>0,5 \mathrm{MW})$. A kutatás jelenlegi szakaszában a villamosenergia-termelés, hútés- és fütés-, valamint a közlekedésienergia-szektorok közül a villamosenergia-termelésre fókuszáltunk. Vizsgálatainkat 2017-re vonatkozóan végeztük el, melynek oka, hogy ez a legkésőbbi év, amelyről minden forrásból korrigáltan és teljeskörúen rendelkezésre álltak releváns adatok.

Az ismertetett előzmények tapasztalatai alapján egy sajátos elméleti módszert alkalmaztunk, amely alapvetően a hazai települések elméleti képességeit vizsgálja a decentralizált helyi megújuló forrásból származó villamosenergia-termelés és -elosztás települési megvalósítási lehetőségei terén.

A magyar villamosenergia-rendszerben, az erőművek teljesítőképessége szerint a Magyar Villamosenergia-ipari Átviteli Rendszerirányító Zrt. (MAVIR) a következő erőmű-kategóriákat különbözteti meg. Alapvetően különbséget tesz az $50 \mathrm{MW}$ alatti kiserőművek, valamint az $50 \mathrm{MW}$ és azt meghaladó teljesítőképességú nagyerőmúvek között. Az 50 MW alatti kategóriákban megkülönbözteti az 50 és 0,5 MW közötti, a 0,5 MW és $50 \mathrm{~kW}$ közötti, valamint az $50 \mathrm{~kW}$ alatti teljesítóképességú kiserőműveket (2007. évi LXXXVI. törvény), (273/2007. (X. 19.) Korm. rendelet). A vizsgálatok során az $50 \mathrm{kVA}(50 \mathrm{~kW})$ és az annál kisebb teljesítményú, nem enge-

Területi Statisztika, 2020, 60(4): 399-424; DOI: 10.15196/TS600401 
délyköteles HMKE-k, valamint a 0,5 MW alatti kiserőművek teljesítményét vettük figyelembe, amelyek létesítését a magyar villamosenergia-törvény 2008. január 1-jétől teszi lehetôvé.

A HMKE-ket alapvetően az intézményi, a vállalati és a lakossági szegmens telepíti saját villamosenergia-szükséglete teljes vagy részleges biztosítására. A villamosenergia-forgalom mérése elektronikus ad-vesz fogyasztásmérő berendezéssel történik. A termelt energiát helyben használják fel, a felesleg pedig a hálózatba kerül. A termelés szünetelése esetén pedig a hálózat biztosítja a szükséges villamos energiát. A szolgáltatók az elszámolást a fogyasztásmérők által rögzített vételezett és betáplált energiamennyiségek összegzésével képzett egyenleg, valamint az aktuális egységárak figyelembevételével végzik. A HMKE-k száma 2008-tól kezdve minden évben dinamikusan növekedett, számuk 2017 végén 29685 db volt, melyek összes beépített teljesítménye elérte a 241,4 MW-ot. Az erőmúvek 99,41\%-a naperőmú, a fennmaradó 0,59\% (a termálvíz-kitermelés melléktermékeként felszínre kerülő) termálmetán-, dízel-, földgáz-, biomassza-, biogáz-, víz- és szélenergiával múködik. A HMKE-k által, a hálózatba betáplált villamos energia mennyisége 2017-ben 105086 MWh-t tett ki (MEKH 2008-2017).

A HMKE-k energiaforrások szerinti összefoglaló adatai, 2017

Summary data of the small-scale household power plants for 2017

\begin{tabular}{l|r|r|r|r|r|r|r|r|r|r}
\hline \multicolumn{1}{c|}{ Megnevezés } & $\begin{array}{c}\text { Nap- } \\
\text { energia }\end{array}$ & $\begin{array}{c}\text { Szél- } \\
\text { energia }\end{array}$ & $\begin{array}{c}\text { Víz- } \\
\text { energia }\end{array}$ & Biogáz & $\begin{array}{c}\text { Bio- } \\
\text { massza }\end{array}$ & $\begin{array}{c}\text { Ter } \\
\text { mál- } \\
\text { me- } \\
\text { tán }\end{array}$ & Földgáz & Dízel & Egyéb & $\begin{array}{c}\text { Össze- } \\
\text { sen }\end{array}$ \\
\hline $\begin{array}{l}\text { Beépített teljesító- } \\
\text { képesség, kW }\end{array}$ & 239960 & 619 & 112 & 115 & 20 & 206 & 291 & 11 & 36 & 241370 \\
$\begin{array}{l}\text { Szám, darab } \\
\begin{array}{l}\text { Hálózatba betáplált } \\
\text { villamos energia, } \\
\text { MWh }\end{array}\end{array}$ & 29510 & 84 & 14 & 28 & 1 & 26 & 20 & 1 & 1 & 29685 \\
& 103626 & 105 & 387 & 32 & 0 & 553 & 258 & 0 & 125 & 105086
\end{tabular}

Forrás: MEKH (2008-2017).

A 0,5 MW alatti kiserőmúvek száma 2017. december 31-ig elérte a 238 db-ot, melyek összes beépített teljesítőképessége 78,2 MW volt. A felhasznált energiahordozók széles spektrumot ölelnek fel, melyek között megújuló és fosszilis energiaforrások is megjelennek. A megújuló energiaforrásokból termelik e kategóriában a villamos energia többségét, amely nap-, szél- és vízenergiából, biogázból, a hulladéklerakóban keletkezett gázból (depóniagázból) és szennyvízgázból származik. A fosszilis energiahordozók csekély mértékben, de megjelennek e kiserőmúvek között, melyek elsősorban a földgáz, termálmetán, egyéb gáz és benzin felhasználásával üzemelnek (MEKH 2008-2017). Az erőmúvek 71\%-a naperőmű, melyet a biogáz és vízerőmúvek követnek, 14 és 10\%-os részesedéssel. A teljesítmény vonatkozásában is a naperőművek állnak az élen, a kategória beépített teljesítményének 78\%-ával,

Területi Statisztika, 2020, 60(4): 399-424; DOI: 10.15196/TS600401 
majd ezt a biogázerőmúvek követik, 14\%-os teljesítményaránnyal. Az energiamixből számottevő még a vízenergia (4\%) és a földgáz hányada is (3\%).

1. ábra

\section{A 0,5 MW alatti kiserőművek számának és beépített teljesítményének energiaforrások szerinti megoszlása, 2017}

Distribution of quantity and built-in capacity of under $0.5 \mathrm{MW}$ capacity small power plants among the energy sources, 2017


Forrás: MEKH (2008-2017).

A 0,5 MW alatti kiserőmúveket - eltérően a HMKE-ktől - már többségében vállalkozások építik, alapvetően üzleti haszonszerzés céljából, csatlakozva a 2016. december 31-ig hatályban lévő Kötelező Átvételi Rendszerhez (KÁT) (2007. évi LXXXVI. törvény, 389/2007. (XII. 23.) Korm. rendelet, 63/2016. (X. 28.) NFM rendelet), valamint az ezt, 2017. január 1-jétől követő Megújuló Támogatási Rendszerhez (METÁR) (2007. évi LXXXVI. törvény, 299/2017. (X. 17.) Korm. rendelet, 62/2016. (XII. 28.) NFM rendelet, 63/2016. (XII. 28.) NFM rendelet, 13/2017. (XI. 8.) MEKH rendelet, 55/2016. (XII. 21.) NFM rendelet).

A települési szintű HMKE-k számának és teljesítményének adatait a Magyarország területén tevékenykedő E.ON Energiaszolgáltató Kft., az ELMÜ-ÉMÁSZ Energiaszolgáltató Zrt. és a Dél-magyarországi Áramszolgáltató Zrt. (DÉMÁSZ) mint egyetemes szolgáltatók, a 0,5 MW alatti kiserômúvekét pedig a Magyar Energetikai és Közmú-szabályozási Hivatal (MEKH) bocsátotta rendelkezésünkre. A pontos, települési szintű villamosenergia-termelési adatokat az egyetemes szolgáltatók, a MEKH és a MAVIR üzleti titoknak minősítették, így azok a vizsgálatainkhoz nem 
álltak rendelkezésre, továbbá az egyetemes szolgáltatók által mért termelési adatok nem tükrözik a HMKE-egységek valós villamosenergia-termelését. Ennek oka az, hogy a termelésből, még a mérőóra előtt elhelyezkedő fogyasztóberendezések által felhasznált energia nem kerül be a hálózatba, így azt nem mérik. Az egyetemes szolgáltatónak csak arról a villamosenergia-mennyiségről van adata, amelyet a termelóberendezés a hálózatba betáplál. Így a rendelkezésre álló adatok alapján nem lehet a megújuló energiaforrásból a településen előállított villamos energia teljes mennyiségét megállapítani. A települési helyi megújuló forrásból származó villamosenergia-termelés adatait ezért a következő elven alapuló számításokkal generáltuk.

Az általunk vizsgált két kategória erőműveinek helyet adó települések önellátási szintjének meghatározásához, az erőművek által elméletileg megtermelhető (napenergia esetén), valamint az átlagos éves kihasználtság alapján meghatározható (egyéb megújuló energiaforrások esetén) villamos energia éves mennyiségét összevetettük a település éves villamosenergia-fogyasztásával, 2017-re vonatkozóan (KSH 2017b). Számításainkat arra alapoztuk, hogy a vizsgált erőmư-kategóriák és ezen belül a helyi megújuló energiaforrásokat hasznosító erőművek milyen arányban képesek kielégíteni a település villamosenergia-igényét.

A napelemes rendszereknél a 2017. év végi települési szintú összteljesítmény adataiból egy elméleti, éves szinten elóállitható villamosenergia-mennyiséget határoztunk meg. A számításokhoz az Európai Bizottság Közös Kutatóközpontja (Ispra, Olaszország) által múködtetett Photovoltaic Geographical Information Systemt használtuk (PVGIS). E szoftverrel a számításokat az összes olyan magyarországi település esetében elvégeztük, ahol HMKE és/vagy 0,5 MW alatti fotovoltaikus (napelem-) kiserőmú mûködöttt.

A többi megújuló energiaforrásnál, azok országos 2017. évi átlagos kihasználtsági adataival határoztuk meg a településen megújuló energiából 2017-ben elvileg megtermelhető villamos energia mennyiségét, melyhez az áltagos kihasználtsági adatokat a MEKH bocsátotta rendelkezésünkre (2. táblázat). Az éves kihasználtsági adat a napenergiáról is rendelkezésre állt, azonban esetében a PVGIS lehetőséget adott pontosabb számítások elvégzésére.

2. táblázat

\section{A megújuló energiaforrást hasznosító HMKE-k és a 0,5 MW alatti kiserőművek átlagos kihasználtsága, 2017}

The average exploitage of the energy efficient small-scale household power plants

(SSHPP) and the small power plants under 0.5 MW capacity in 2017

\begin{tabular}{c|c|r|r|r|r|r|r}
\hline Megnevezés & $\begin{array}{c}\text { Nap- } \\
\text { energia }\end{array}$ & $\begin{array}{c}\text { Szél- } \\
\text { energia }\end{array}$ & $\begin{array}{c}\text { Víz- } \\
\text { energia }\end{array}$ & Biogáz & $\begin{array}{c}\text { Bio- } \\
\text { massza }\end{array}$ & $\begin{array}{c}\text { Depónia- } \\
\text { gáz }\end{array}$ & $\begin{array}{c}\text { Szenny- } \\
\text { vízgáz }\end{array}$ \\
\hline Átlagos kihasználtság, \% & 15,2 & 25,9 & 40,9 & 46,5 & 60,1 & 57,1 & 50,9
\end{tabular}

Forrás: MAVIR (2017).

Területi Statisztika, 2020, 60(4): 399-424; DOI: 10.15196/TS600401 
Az egyéb energiahordozók közül a benzin, a dízel, a földgáz, a gáz és a termálmetán alapú kiserőműveket, mint a vizsgálatok szempontjából nem releváns fosszilis energiahordozókat nem vettük figyelembe. A számításokat Magyarország 3155 települési önkormányzatának területére vonatkozóan végeztük el (KSH 2017a).

\section{Eredmények}

$\mathrm{Az}$ ismertetett adatok és módszerek alkalmazásával a helyi megújuló energiából származó villamosenergia-önellátás települési szintjének vizsgálatát egyedileg és összevontan is elvégeztük Magyarország összes településére vonatkozóan. Az adatokat lefuttattuk a HMKE-k, majd a 0,5 MW alatti kiserőmúvek esetében, végül a két erőmű-kategóriát összevonva, azok együttes teljesítményét vizsgáltuk.

\section{A HMKE-k teljesítőképessége}

Először az ebbe a kategóriába tartozó megújuló energiaforrást hasznosító erőművek teljesítményét határoztuk meg. A 3155 magyarországi település közül 2200 településen létesítettek 2008. január 1. és 2017. december 31. között HMKE-t, tehát további 955 településen nincsen megújuló energiát hasznosító HMKE. A kapott eredmények alapján ez az erőmű-kategória összesen 4 településen képes kielégíteni a villamosenergia-igények 100\%-át. Ezek a települések mindegyike 1500 főnél kisebb lélekszámú (3. táblázat). A rangsor élén a 262 fős Sóstófalva áll, 388\%-os helyi megújuló forrásból származó villamosenergia-termeléssel, tehát a falu éves villamosenergia-igényének közel négyszeresét termeli meg a saját területén, kizárólag ebben az erőmű-kategóriában, a megújuló energiaforrások közül csak napenergiát használva. A második helyen a 176 fős Csonkamindszent áll, ahol a megújuló energiaforrásokkal az igények 143\%-át biztosítják, szintén napenergia felhasználásával. A harmadik Bodrogkeresztúr 128\%-kal, ahol már biogázból származik a HMKE-k által termelt energia $85 \%$-a, a további $15 \%$ pedig napenergiából. E település kiemelkedő a tekintetben, hogy az előbbi néhány száz fős falvakhoz képest ez már egy 1102 fős község. A negyedik, a 64 fős Nagyhuta, 102\%-kal, ahol a villamosenergiaigényeket ugyancsak napelemek biztosítják.

\section{A 0,5 MW alatti kiserőmúvek teljesítőképessége}

A települési villamosenergia-önellátás vizsgálatának második szakaszában a 0,5 MW alatti kiserőművek teljesítményét határoztuk meg az erőműveknek helyet adó település villamosenergia-ellátásában. A 2017 végéig létesített 238 erőmủ 195 településen múködik, melyek közül 23 településen az éves termelés meghaladja a szükségleteket (3. táblázat). Az igényeihez képest legtöbb (534\%) villamos energiát a 200 lakosú Ipacsfa termeli. A 4. táblázat adatai szerint az elsô 11 település villamosenergia- 
igényének többszörösét állítja elő megújuló energiaforrásokat felhasználó kiserőművi termelésből. A lista elején alacsony lélekszámú kisfalvak szerepelnek, azonban Hejőpapi, Buzsák, Zalaszentmihály és Csörög lakossága már 1000 és 2000 fő közötti. Az erőmúvek többsége itt is naperőmű, azonban a rangsorban 2. Gibárt, 16. Csörötnek, valamint 20. Pornóapáti a vízenergia hasznosításával termel jelentős mennyiségű villamos energiát. Kivételt képez még Hejőpapi és Csörög, ahol depóniagázt, valamint Zalaszentmihály, ahol biogázt hasznosítanak. E 23 településnél nem jellemző a megújuló energiamix, mivel mindenhol egyetlen megújuló energiaforrásból származik a megtermelt villamos energia.

\section{A HMKE-k és a 0,5 MW alatti kiserőmúvek összevont villamosenergia- termelő képessége}

Vizsgálatunk harmadik szakaszában, az előző két alfejezet kiserőmú-kategóriáinak összevont teljesítményével határoztuk meg az önellátottság szintjét. E szerint 2017ben 30 olyan település volt Magyarországon, amelyek területén múködő megújuló energiaforrást hasznosító HMKE-k és/vagy 0,5 MW alatti kiserőművek a település éves villamosenergia-igényének több mint 100\%-át tudták biztosítani (3. táblázat). Míg a 30 település 80\%-a 1000 fó alatti, addig 20\%-a 1000 fó feletti, a legnépesebb közöttük Csörög, 2148 fóvel. Az éves igényéhez képest a legtöbb áramot Sóstófalva (558\%) állítja elő. Nem sokkal marad el tôle Ipacsfa (534\%) és Gibárt (493\%). Sóstófalva esetében az összes megújuló energiát hasznosító erômú napenergiával múködik, azonban megkülönböztettük a HMKE-ből és a 0,5 MW alatti kiserőmúből származó villamos energiát is, arányuk $70 / 30 \%$. Ezt az elvet a többi, 2. ábrán szereplő településnél is követtük. Ipacsfa megújuló forrásból származó villamos energiájának egészét napenergia-alapú kiserőművek termelik, míg Gibárton a helyi vízerőmú, amely szintén a 0,5 MW alatti erőmú-kategóriába tartozik. A 30 település erőmúveinek többsége kiserőművi napenergia-hasznosítással termel, kivéve Demjént, ahol a HMKE adja a villamos energia többségét. Összetettebb energiamix Bodrogkeresztúron figyelhetô meg, ahol a 9\% napenergia mellett a depóniagáz 35, míg a biogáz 56\%-át adja a megújuló energiaforrásból származó villamos energiának. Csörötnek településen a vízenergia teszi ki a termelés 98\%-át, a $2 \%$ napenergia mellett. Csomádon a kiserômúvi biogáz 34\%-án túl további 58\% származik HMKE biogázerômúvekből, a 8\% HMKE napenergia mellett. Hasonló a helyzet Nógrádkövesden is, ahol a kiserőmúvi biogáz, a HMKE biogáz és a napenergia aránya 33/66/1\%. Pornóapátiban a termelt villamos energia 98\%-a vízenergiából, 2\%-a napenergiából, Zalaszentmihályon 98\% biogázból, 2\% napenergiából, végül Csörögön 97\% depóniagázból, 3\% pedig szintén napenergiából származik.

Területi Statisztika, 2020, 60(4): 399-424; DOI: 10.15196/TS600401 
3. táblázat

\section{A kiserőművek által helyi megújuló energiaforrásból összevontan termelt villamos energia aránya az így önellátóvá váló települések villamosenergia-igényében, 2017}

The proportion of electricity from local renewable energy sources in the electricity demand in case of the self-sufficient settlements: in the small-scale household power plants category; in the under $0.5 \mathrm{MW}$ capacity small power plants; and by the two power plants category in 2017

\begin{tabular}{|c|c|c|c|c|c|c|c|c|c|c|c|}
\hline \multicolumn{4}{|c|}{ A HMKE-k } & \multicolumn{4}{|c|}{ A 0,5 MW alatti kiserőmúvek } & \multicolumn{4}{|c|}{ A két erőmű-kategória összevont } \\
\hline \multicolumn{12}{|c|}{ teljesítménye alapján } \\
\hline & település & $\begin{array}{c}\text { saját } \\
\text { terme- } \\
\text { lés }\end{array}$ & $\begin{array}{c}\text { népes- } \\
\text { ség, } \\
\text { fố }\end{array}$ & & település & $\begin{array}{l}\text { saját } \\
\text { terme- } \\
\text { lés }\end{array}$ & $\begin{array}{l}\text { népes- } \\
\text { ség, fö }\end{array}$ & & település & $\begin{array}{l}\text { saját } \\
\text { terme- } \\
\text { lés }\end{array}$ & $\begin{array}{c}\text { népes- } \\
\text { ség, } \\
\text { fố }\end{array}$ \\
\hline 1 & Sóstófalva & 388 & 262 & 1 & Ipacsfa & 534 & 200 & 1 & Sóstófalva & 558 & 262 \\
\hline 2 & Csonkamindszent & 143 & 176 & 2 & Gibárt & 493 & 335 & 2 & Ipacsfa & 534 & 200 \\
\hline 3 & Bodrogkeresztúr & 128 & 1102 & 3 & Galvács & 391 & 87 & 3 & Gibárt & 493 & 335 \\
\hline 4 & Nagyhuta & 102 & 64 & 4 & Vekerd & 346 & 119 & 4 & Galvács & 391 & 87 \\
\hline & & & & 5 & Csanádalberti & 280 & 468 & 5 & Vekerd & 346 & 119 \\
\hline & & & & 6 & Barnag & 260 & 142 & 6 & Csanádalberti & 280 & 468 \\
\hline & & & & 7 & Ganna & 232 & 269 & 7 & Barnag & 272 & 142 \\
\hline & & & & 8 & Tiszadorogma & 224 & 377 & 8 & Illocska & 252 & 268 \\
\hline & & & & 9 & Illocska & 222 & 268 & 9 & Tiszadorogma & 234 & 377 \\
\hline & & & & 10 & Alsótelekes & 219 & 140 & 10 & Ganna & 232 & 269 \\
\hline & & & & 11 & Kupa & 204 & 186 & 11 & Alsótelekes & 224 & 140 \\
\hline & & & & 12 & Sóstófalva & 170 & 262 & 12 & Kupa & 204 & 186 \\
\hline & & & & 13 & Somogyhatvan & 167 & 372 & 13 & Bodrogkeresztúr & 197 & 1102 \\
\hline & & & & 14 & Peterd & 165 & 223 & 14 & Egyházasharaszti & 168 & 334 \\
\hline & & & & 15 & Egyházasharaszti & 164 & 334 & 15 & Somogyhatvan & 167 & 372 \\
\hline & & & & 16 & Csörötnek & 161 & 862 & 16 & Peterd & 165 & 223 \\
\hline & & & & 17 & Kémes & 156 & 475 & 17 & Csörötnek & 165 & 862 \\
\hline & & & & 18 & Hejőpapi & 125 & 1175 & 18 & Kémes & 156 & 475 \\
\hline & & & & 19 & Buzsák & 125 & 1525 & 19 & Csomád & 149 & 1631 \\
\hline & & & & 20 & Pornóapáti & 120 & 384 & 20 & Csonkamindszent & 143 & 176 \\
\hline & & & & 21 & Zalaszentmihály & 114 & 1005 & 21 & Nógrádkövesd & 142 & 660 \\
\hline & & & & 22 & Hejce & 111 & 223 & 22 & Hejce & 132 & 223 \\
\hline & & & & 23 & Csörög & 109 & 2148 & 23 & Buzsák & 127 & 1525 \\
\hline & & & & & & & & 24 & Pornóapáti & 125 & 384 \\
\hline & & & & & & & & 25 & Hejőpapi & 125 & 1175 \\
\hline & & & & & & & & 26 & Zalaszentmihály & 116 & 1005 \\
\hline & & & & & & & & 27 & Csörög & 112 & 2148 \\
\hline & & & & & & & & 28 & Bojt & 106 & 598 \\
\hline & & & & & & & & 29 & Nagyhuta & 102 & 64 \\
\hline & & & & & & & & 30 & Demjén & 101 & 613 \\
\hline
\end{tabular}

a) A villamosenergia-igény százalékában. 


\section{Az energiaexport lehetőségének vizsgálata az önellátó településeken}

Eredményeink ismeretében, a következő lépésben azt mutattuk ki, hogy a túltermelő települések az általuk fel nem használt villamos energiával mekkora szomszédos települési körzetet képesek ellátni. A korábban alkalmazott módszerhez hasonlóan először a HMKE-k által megtermelhető villamos energiát vettük figyelembe, ezt követően a 0,5 MW alatti kiserőművekét, végül a két erőmű-kategória együttes teljesítményét. A túltermelő település által termelt, felesleges villamos energia átadási irányának kiválasztásakor azt a szempontot követtük, hogy minél több, megújuló forrásból származó villamos energiával ellátott települést kapjunk. Míg az ellátott települések egy részénél a zöldáram ${ }^{1}$ teljes mértékben a túltermelő településről származik, addig másoknál a helyben termelt megújuló forrású villamos energiát egészíti ki.

\section{Túltermelő települések és energiaexportjuk a HMKE-kategóriában}

A korábbi eredményeink azt mutatták, hogy a megújuló energiával múködő HMKE-k éves elméleti villamosenergia-termelése 4 településen haladja meg a fogyasztást. Ezen települések közül Sóstófalva, a szomszédos Alsódobsza 2\%-os HMKE megújuló forrásból származó villamosenergia-fogyasztása mellett a település igényének további 98\%-át képes biztosítani, így elérve a megújuló energiaforrások100\%-os arányát (4. táblázat). Emellett a szintén szomszédos Újcsanálosnak is képes átadni további 506 MWh-t, ami a falu éves villamosenergia-igényének 46\%-a. Bodrogkeresztúr, a saját éves fogyasztása mellett Szegi villamosenergia-igényét képes teljes egészében fedezni, valamint Zalkod fogyasztásának 60\%-át. Csonkamindszent és Nagyhuta már csak részben képes Dinnyeberki (55\%), valamint Vágáshuta (66\%) éves áramigényét biztosítani az általa termelt többletenergiával. Tegyük hozzá, hogy ez Vágáshuta esetében az igények mindössze 3\%-a, mivel itt a szintén megújuló forrásból származó 63\%-ot maga az exportban részesülő település állítja elő. Tehát a HMKE-kategóriában túltermelő 4 település további kettő villamosenergia-igényét tudja 100\%-ban fedezni, illetve azt 100\%-ra kiegészíteni (4. táblázat). Összegezve tehát a megújuló forrásokat használó HMKE-k 4 magyarországi települést képesek önellátóvá tenni a villamosenergia-fogyasztás terén, amelyek energiafeleslegükkel további 2 településen képesek a 100\%-os arányt biztosítani.

\footnotetext{
${ }^{1}$ A tanulmányban a zöldáram és a megújuló forrásból származó villamos energia egymás szinonimái.
}

Területi Statisztika, 2020, 60(4): 399-424; DOI: 10.15196/TS600401 
A HMKE-k által villamosenergia-túltermelő települések és az energiatranszport jóvoltából teljesen vagy részlegesen önellátóvá váló települések főbb ellátási adatai, villamosenergia-igényük százalékában, 2017

The electricity overproducing settlements with small-scale household power plants (SSHPP) and main supply data of totally or partially self-sufficient settlements due to energy transport, in the proportion of their electricity demand, 2017

\begin{tabular}{|c|c|c|c|c|c|c|c|c|c|c|}
\hline \multicolumn{6}{|c|}{ A HMKE-k teljesítménye alapján } & \multicolumn{5}{|c|}{$\begin{array}{c}\text { A HMKE-k teljesítménye és } \\
\text { energiaimport alapján a) }\end{array}$} \\
\hline & \multirow{2}{*}{ település } & \multicolumn{2}{|c|}{ saját termelés a) } & $\begin{array}{l}\text { energia- } \\
\text { export }\end{array}$ & & & \multirow{2}{*}{ település } & $\begin{array}{l}\text { saját } \\
\text { terme- }\end{array}$ & $\begin{array}{c}\text { energia- } \\
\text { import }\end{array}$ & együtt \\
\hline & & $\%$ & \multicolumn{2}{|c|}{ MWh } & & & & \multicolumn{3}{|c|}{$\%$} \\
\hline \multirow[t]{2}{*}{1} & Sóstófalva & 388 & 1230 & 407 & $\rightarrow$ & 1 & Alsódobsza & 2 & 98 & 100 \\
\hline & & & & 506 & $\rightarrow$ & & Újcsanálos & 0 & 46 & 46 \\
\hline 2 & Csonkamindszent & 143 & 289 & 87 & $\rightarrow$ & & Dinnyeberki & 0 & 55 & 55 \\
\hline \multirow[t]{2}{*}{3} & Bodrogkeresztúr & 128 & 2797 & 460 & $\rightarrow$ & 2 & Szegi & 0 & 100 & 100 \\
\hline & & & & 159 & $\rightarrow$ & & Zalkod & 0 & 60 & 60 \\
\hline 4 & Nagyhuta & 102 & 240 & 4 & $\rightarrow$ & & Vágáshuta & 63 & 3 & 66 \\
\hline
\end{tabular}

a) A villamosenergia-igény százalékában.

\section{Túltermelő települések és energiaexportjuk a 0,5 MW alatti kiserőmü- kategóriában}

Amennyiben kizárólag a 0,5 MW alatti kiserőmúvek csak megújuló energiaforrást hasznosító teljesítményét vesszük figyelembe, akkor azok a nekik helyet adó települések közül 23-nak képesek az éves villamosenergia-igényét 100\%-ig, illetve afölött biztosítani (5. táblázat). A villamosenergia-többletüket a szomszédos településeknek átadva további 20 település válik önellátóvá, az általuk igényelt áram 100\%-ának, illetve bizonyos arányának biztosításával. A 20 ellátott településből 16 önellátását 100\%-ig a szomszédos, túltermelő település biztosítja teljesen megújuló forrásból, míg 4 ellátott település esetében a helyben megújuló forrásból termelt villamos energiát egészíti ki a túltermelő települések exportja. Az ezen felül fennmaradó zöldáram még további 21 település éves fogyasztásának bizonyos százalékát is fedezni tudja, melynek aránya $1 \%$ és $94 \%$ közötti.

Éves szinten a legtöbb energiát Buzsák naperőművei állítják elő, azonban mindössze Táska áramigényét képes megújuló energiaforrásból ellátni, igaz azt 100\%-ig. Emellett még további 81 MWh-át exportálhat Nikla településnek, amelynél így 9\%-ban megújuló forrásból származik a helyi villamosenergia-fogyasztás. A Buzsák által ellátható szomszédos települések alacsony száma a magas termelés melletti, magas helyi fogyasztással magyarázható, ugyanis a község több mint 1500 fős. 
A legtöbb szomszédos települést Gibárt képes önellátóvá tenni, a Hernádon működő kis vízerőmű termelésével, ezek Hernádbűd, Hernádcéce és Pere, továbbá a fennmaradó 361 MWh-val még Abaújkér (49\%) ellátásához is hozzájárul. Tehát a 0,5 MW alatti kiserőmű-kategóriában túltermelő 23 település további 20 települést képes önellátóvá tenni, valamint 4 település éves igényét megújuló forrásból származó villamos energiával eltérő arányban fedezni.

5. táblázat

A 0,5 MW alatti kiserőművek által villamosenergia-túltermelő települések és az energiatranszport jóvoltából teljesen vagy részlegesen önellátóvá váló települések főbb ellátási adatai, villamosenergia-igényük százalékában, 2017

Electricity overproducing settlements with small power plants under $0.5 \mathrm{MW}$ capacity and main supply data of totally or partially self-sufficient settlements due to energy transport in the proportion of their electricity demand, 2017

\begin{tabular}{|c|c|c|c|c|c|c|c|c|c|c|}
\hline \multicolumn{6}{|c|}{ A 0,5 MW alatti kiserőművek teljesítménye alapján } & \multicolumn{5}{|c|}{$\begin{array}{l}\text { A 0,5 MW alatti kiserőművek teljesítménye és } \\
\text { energiaimport alapján a) }\end{array}$} \\
\hline & \multirow{2}{*}{ település } & \multicolumn{2}{|c|}{ saját termelés a) } & \multirow{2}{*}{$\begin{array}{l}\text { energia- } \\
\text { export }\end{array}$} & & & \multirow{2}{*}{ település } & $\begin{array}{c}\text { saját } \\
\text { terme- }\end{array}$ & energia- & együtt \\
\hline & & $\%$ & MWh & & & & & \multicolumn{3}{|c|}{$\%$} \\
\hline \multirow[t]{3}{*}{1} & Ipacsfa & 534 & 1170 & 476 & $\rightarrow$ & 1 & Gordisa & 0 & 100 & 100 \\
\hline & & & & 353 & $\rightarrow$ & 2 & Drávaszerdahely & 0 & 100 & 100 \\
\hline & & & & 122 & $\rightarrow$ & & Kovácshida & 0 & 34 & 34 \\
\hline \multirow[t]{4}{*}{2} & Gibárt & 493 & 1755 & 175 & $\rightarrow$ & 3 & Hernádbűd & 0 & 100 & 100 \\
\hline & & & & 410 & $\rightarrow$ & 4 & Hernádcéce & 0 & 100 & 100 \\
\hline & & & & 453 & $\rightarrow$ & 5 & Pere & 0 & 100 & 100 \\
\hline & & & & 361 & $\rightarrow$ & & Abaújkér & 0 & 49 & 49 \\
\hline \multirow[t]{2}{*}{3} & Galvács & 391 & 528 & 291 & $\rightarrow$ & 6 & Rakacaszend & 0 & 100 & 100 \\
\hline & & & & 102 & $\rightarrow$ & & Abod & 0 & 24 & 24 \\
\hline \multirow[t]{2}{*}{4} & Vekerd & 346 & 554 & 385 & $\rightarrow$ & 7 & Darvas & 59 & 41 & 100 \\
\hline & & & & 9 & $\rightarrow$ & & Magyarhomorog & 27 & 1 & 28 \\
\hline \multirow[t]{2}{*}{5} & Csanádalberti & 280 & 1580 & 992 & $\rightarrow$ & 8 & Pitvaros & 53 & 47 & 100 \\
\hline & & & & 23 & $\rightarrow$ & & Mezőhegyes & 6 & 1 & 7 \\
\hline \multirow[t]{2}{*}{6} & Barnag & 260 & 571 & 150 & $\rightarrow$ & 9 & Vöröstó & 0 & 100 & 100 \\
\hline & & & & 201 & $\rightarrow$ & & Hidegkút & 0 & 27 & 27 \\
\hline 7 & Ganna & 232 & 1080 & 615 & $\rightarrow$ & & Döbrönte & 0 & 79 & 79 \\
\hline 8 & Tiszadorogma & 224 & 1630 & 895 & $\rightarrow$ & 10 & Tiszabábolna & 0 & 100 & 100 \\
\hline \multirow[t]{2}{*}{9} & Illocska & 222 & 570 & 233 & $\rightarrow$ & 11 & Magyarbóly & 83 & 17 & 100 \\
\hline & & & & 80 & $\rightarrow$ & & Ivándárda & 0 & 26 & 26 \\
\hline \multirow[t]{2}{*}{10} & Alsótelekes & 219 & 1040 & 188 & $\rightarrow$ & 12 & Szőlősardó & 0 & 100 & 100 \\
\hline & & & & 377 & $\rightarrow$ & & Felsőtelekes & 0 & 51 & 51 \\
\hline 11 & Kupa & 204 & 532 & 271 & $\rightarrow$ & & Tomor & 0 & 86 & 86 \\
\hline
\end{tabular}

Területi Statisztika, 2020, 60(4): 399-424; DOI: 10.15196/TS600401 
(Folytatás.)

\begin{tabular}{|c|c|c|c|c|c|c|c|c|c|c|}
\hline \multicolumn{6}{|c|}{ A 0,5 MW alatti kiserőmûvek teljesítménye alapján } & \multicolumn{5}{|c|}{$\begin{array}{c}\text { A 0,5 MW alatti kiserőmúvek teljesítménye és } \\
\text { energiaimport alapján a) }\end{array}$} \\
\hline & \multirow{2}{*}{ település } & \multicolumn{2}{|c|}{ saját termelés a) } & \multirow{2}{*}{$\begin{array}{c}\text { energia- } \\
\text { export }\end{array}$} & & & \multirow{2}{*}{ település } & $\begin{array}{l}\text { saját } \\
\text { terme- }\end{array}$ & $\begin{array}{l}\text { energia- } \\
\text { import }\end{array}$ & \multirow[t]{2}{*}{ együtt } \\
\hline & & $\%$ & \multicolumn{2}{|c|}{ MWh } & & & & \multicolumn{2}{|r|}{$\%$} & \\
\hline 12 & Sóstófalva & 170 & 540 & 223 & $\rightarrow$ & & Alsódobsza & 0 & 70 & 70 \\
\hline \multirow[t]{2}{*}{13} & Somogyhatvan & 167 & 565 & 197 & $\rightarrow$ & 13 & Visnye & 0 & 100 & 100 \\
\hline & & & & 30 & $\rightarrow$ & & Patapoklosi & 0 & 8 & 8 \\
\hline \multirow[t]{2}{*}{14} & Peterd & 165 & 506 & 140 & $\rightarrow$ & 14 & Pécsdevecser & 0 & 100 & 100 \\
\hline & & & & 60 & $\rightarrow$ & & Lothárd & 0 & 20 & 20 \\
\hline \multirow[t]{2}{*}{15} & Egyházasharaszti & 164 & 1160 & 416 & $\rightarrow$ & 15 & Siklósnagyfalu & 0 & 100 & 100 \\
\hline & & & & 36 & $\rightarrow$ & & Old & 0 & 8 & 8 \\
\hline \multirow[t]{2}{*}{16} & Csörötnek & 161 & 1737 & 94 & $\rightarrow$ & 16 & Magyarlak & 90 & 10 & 100 \\
\hline & & & & 562 & $\rightarrow$ & & Vasszentmihály & 0 & 84 & 84 \\
\hline \multirow[t]{3}{*}{17} & Kémes & 156 & 1170 & 155 & $\rightarrow$ & 17 & Adorjás & 0 & 100 & 100 \\
\hline & & & & 93 & $\rightarrow$ & 18 & Drávapiski & 0 & 100 & 100 \\
\hline & & & & 173 & $\rightarrow$ & & Tésenfa & 0 & 94 & 94 \\
\hline 18 & Hejőpapi & 125 & 2481 & 491 & $\rightarrow$ & & Szakáld & 0 & 70 & 70 \\
\hline \multirow[t]{2}{*}{19} & Buzsák & 125 & 2810 & 472 & $\rightarrow$ & 19 & Táska & 0 & 100 & 100 \\
\hline & & & & 81 & $\rightarrow$ & & Nikla & 0 & 9 & 9 \\
\hline 20 & Pornóapáti & 120 & 931 & 154 & $\rightarrow$ & & Horvátlövő & 0 & 52 & 52 \\
\hline \multirow[t]{2}{*}{21} & Zalaszentmihály & 114 & 2028 & 179 & $\rightarrow$ & 20 & Zalaigrice & 0 & 100 & 100 \\
\hline & & & & 64 & $\rightarrow$ & & Nemesszentandrás & 0 & 20 & 20 \\
\hline 22 & Hejce & 111 & 527 & 52 & $\rightarrow$ & & Korlát & 0 & 12 & 12 \\
\hline 23 & Csörög & 109 & 2496 & 200 & $\rightarrow$ & & Vácduka & 0 & 10 & 10 \\
\hline
\end{tabular}

Túltermelő települések és energiaexportjuk a HMKE-k és a 0,5 MW alatti kiserőmúvek összevont teljesítménye alapján

A HMKE-k és a 0,5 MW alatti kiserőmúvek villamosenergia-termelésének összevonásával 30 magyarországi település képes biztosítani éves villamosenergia-igényét (2. ábra). Amennyiben e települések zöldáramtöbbletüket a szomszédos települések felé továbbítják, úgy további 29 település éves villamosenergia-szükséglete biztosítható 100\%-ig, valamint 30 településé eltérő (1 és 96\% közötti) arányban kiegészíthető (6. táblázat). A legtöbb szomszédos települést Gibárt (Pere, Hernádbűd, Hernádcéce) és Nógrádkövesd (Legénd, Szécsénke, Szanda) képes ellátni, mellyel ezek is 100\%-ban megújuló forrásokat használó decentralizált kiserômúvekből származó villamos energiával biztosíthatják éves igényüket. A legtöbb megújuló forrásból származó villamos energiát Nógrádkövesd (6118 MWh/év) állítja elő biogázból és 
napenergiából, valamint Bodrogkeresztúr (4227 MWh/év) biogázból, depóniagázból és napenergiából. E két erőmú-kategória összevont megújuló forrású villamosenergia-termelő képességének vizsgálata azt mutatja, hogy saját termeléssel és a felesleg helyi exportjával 59 település válhat önellátóvá Magyarországon a decentralizált elhelyezkedésű, helyben termelt, megújuló forrást hasznosító kiserőművi villamosenergia-termelés és -elosztás által.

2. ábra

\section{A HMKE-k és a 0,5 MW alatti kiserőművek által önellátó}

(villamosenergia-túltermelő) települések főbb adatai, 2017

Self-sufficient settlements in Hungary: the combined ratio of small-scale household power plants (SSHPP) and small power plants under $0.5 \mathrm{MW}$ capacity generated renewable electricity in the electricity consumption of settlements

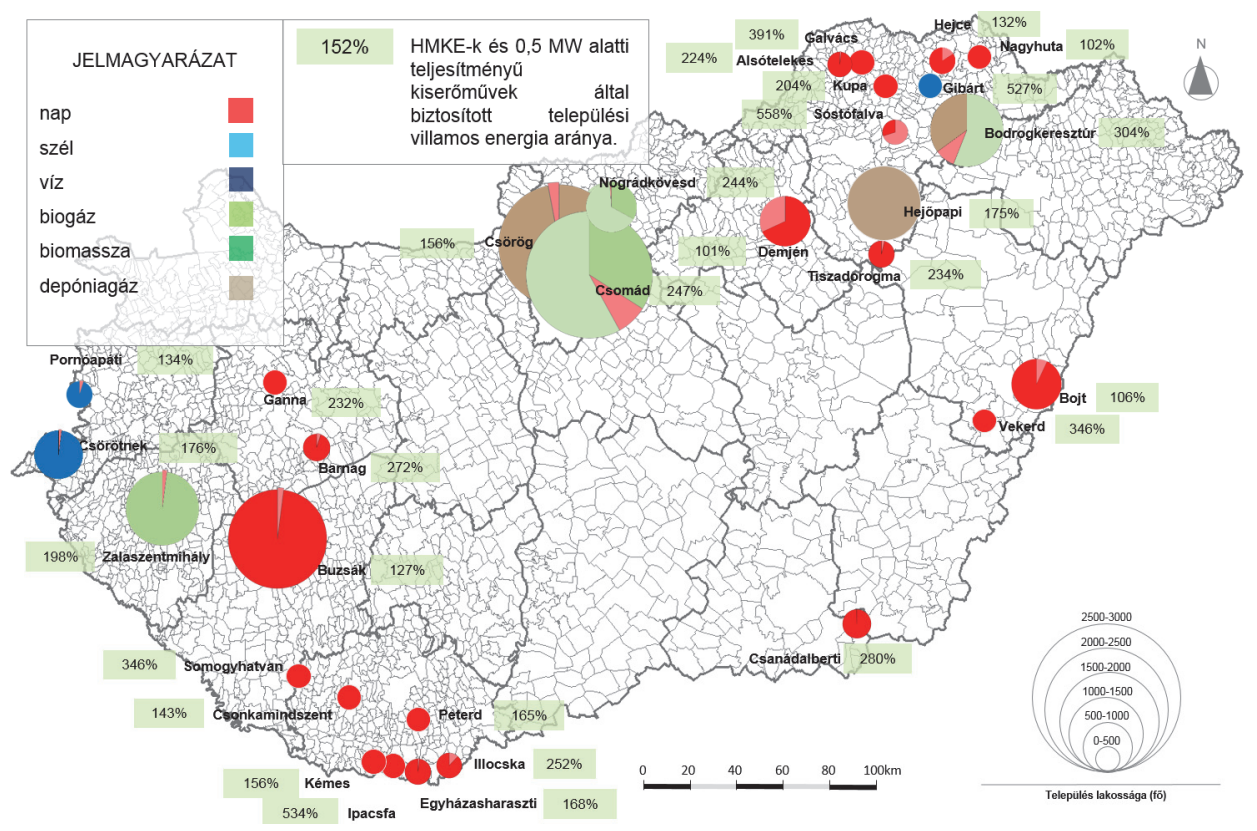

Területi Statisztika, 2020, 60(4): 399-424; DOI: 10.15196/TS600401 
6. táblázat

A HMKE-k és a 0,5 MW alatti kiserőművek által villamosenergia-túltermelő települések, valamint az energiatranszport jóvoltából teljesen vagy részlegesen önellátóvá váló települések főbb ellátási adatai, 2017

Electricity overproducing settlements where small-scale household power plants (SSHPP) and small power plants under $0.5 \mathrm{MW}$ capacity as well as main supply data of totally or partially self-sufficient settlements due to energy transport, 2017

\begin{tabular}{|c|c|c|c|c|c|c|c|c|c|c|}
\hline \multicolumn{6}{|c|}{$\begin{array}{l}\text { A HMKE-k és a 0,5 MW alatti kiserőmúvek } \\
\text { összevont teljesítménye alapján }\end{array}$} & \multicolumn{5}{|c|}{$\begin{array}{c}\text { A HMKE-k és a 0,5 MW alatti kiserőművek } \\
\text { összevont teljesítménye, valamint } \\
\text { energiaimport alapján a) }\end{array}$} \\
\hline & \multirow[t]{2}{*}{ település } & \multirow{2}{*}{$\begin{array}{l}\text { saját } \\
\text { terme- } \\
\text { lés, } \% \text { a) }\end{array}$} & $\begin{array}{l}\text { saját } \\
\text { terme- } \\
\text { lés }\end{array}$ & $\begin{array}{l}\text { energia } \\
\text { export }\end{array}$ & & & \multirow[t]{2}{*}{ település } & $\begin{array}{l}\text { saját } \\
\text { terme- } \\
\text { lés }\end{array}$ & $\begin{array}{l}\text { energia- } \\
\text { import }\end{array}$ & együtt \\
\hline & & & \multicolumn{2}{|c|}{ MWh } & & & & \multicolumn{3}{|c|}{$\%$} \\
\hline 1 & Sóstófalva & 558 & 1770 & $\begin{array}{l}407 \\
931 \\
115\end{array}$ & $\begin{array}{l}\rightarrow \\
\rightarrow\end{array}$ & $\begin{array}{l}1 \\
2\end{array}$ & $\begin{array}{l}\text { Alsódobsza } \\
\text { Újcsanálos } \\
\text { Onga }\end{array}$ & $\begin{array}{r}2 \\
0 \\
95\end{array}$ & $\begin{array}{r}98 \\
100 \\
1\end{array}$ & $\begin{array}{r}100 \\
100 \\
96\end{array}$ \\
\hline 2 & Ipacsfa & 534 & 1170 & $\begin{array}{l}459 \\
353 \\
139\end{array}$ & $\begin{array}{l}\rightarrow \\
\rightarrow \\
\rightarrow\end{array}$ & $\begin{array}{l}3 \\
4\end{array}$ & $\begin{array}{l}\text { Gordisa } \\
\text { Drávaszerdahely } \\
\text { Kovácshida }\end{array}$ & $\begin{array}{l}3 \\
0 \\
0\end{array}$ & $\begin{array}{r}97 \\
100 \\
39 \\
\end{array}$ & $\begin{array}{r}100 \\
100 \\
39 \\
\end{array}$ \\
\hline 3 & Gibárt & 493 & 1755 & $\begin{array}{l}453 \\
175 \\
386 \\
385\end{array}$ & $\begin{array}{l}\rightarrow \\
\rightarrow \\
\rightarrow\end{array}$ & $\begin{array}{l}5 \\
6 \\
7\end{array}$ & $\begin{array}{l}\text { Pere } \\
\text { Hernádbűd } \\
\text { Hernádcéce } \\
\text { Abaújkér }\end{array}$ & $\begin{array}{r}0 \\
0 \\
5 \\
17 \\
\end{array}$ & $\begin{array}{r}100 \\
100 \\
95 \\
53\end{array}$ & $\begin{array}{r}100 \\
100 \\
100 \\
70 \\
\end{array}$ \\
\hline 4 & Galvács & 391 & 528 & \begin{tabular}{r|}
91 \\
291 \\
13 \\
\end{tabular} & $\begin{array}{l}\rightarrow \\
\rightarrow \\
\rightarrow\end{array}$ & $\begin{array}{l}8 \\
9\end{array}$ & $\begin{array}{l}\text { Abod } \\
\text { Rakacaszend } \\
\text { Szalonna }\end{array}$ & $\begin{array}{r}77 \\
0 \\
4 \\
\end{array}$ & $\begin{array}{r}23 \\
100 \\
1 \\
\end{array}$ & $\begin{array}{r}100 \\
100 \\
5 \\
\end{array}$ \\
\hline 5 & Vekerd & 346 & 554 & \begin{tabular}{r|}
383 \\
11 \\
\end{tabular} & $\begin{array}{l}\rightarrow \\
\rightarrow\end{array}$ & 10 & $\begin{array}{l}\text { Darvas } \\
\text { Magyarhomorog }\end{array}$ & $\begin{array}{l}59 \\
28\end{array}$ & $\begin{array}{r}41 \\
1 \\
\end{array}$ & $\begin{array}{r}100 \\
29 \\
\end{array}$ \\
\hline 6 & Csanádalberti & 280 & 1583 & $\begin{array}{l}914 \\
114\end{array}$ & $\rightarrow$ & 11 & $\begin{array}{l}\text { Pitvaros } \\
\text { Ambrózfalva }\end{array}$ & $\begin{array}{r}57 \\
3\end{array}$ & $\begin{array}{l}43 \\
16\end{array}$ & $\begin{array}{r}100 \\
19 \\
\end{array}$ \\
\hline 7 & Barnag & 272 & 598 & $\begin{array}{l}144 \\
234\end{array}$ & $\begin{array}{l}\rightarrow \\
\rightarrow\end{array}$ & 12 & $\begin{array}{l}\text { Vöröstó } \\
\text { Hidegkút }\end{array}$ & $\begin{array}{l}3 \\
1\end{array}$ & $\begin{array}{l}97 \\
31\end{array}$ & $\begin{array}{r}100 \\
32\end{array}$ \\
\hline 8 & Illocska & 252 & 647 & $\begin{array}{l}190 \\
200\end{array}$ & $\begin{array}{l}\rightarrow \\
\rightarrow\end{array}$ & 13 & $\begin{array}{l}\text { Magyarbóly } \\
\text { Ivándárda }\end{array}$ & $\begin{array}{r}86 \\
0\end{array}$ & $\begin{array}{l}14 \\
65\end{array}$ & $\begin{array}{r}100 \\
65 \\
\end{array}$ \\
\hline 9 & Tiszadorogma & 234 & 1700 & $\begin{array}{r}895 \\
77\end{array}$ & $\rightarrow$ & 14 & $\begin{array}{l}\text { Tiszabábolna } \\
\text { Ároktó }\end{array}$ & $\begin{array}{l}2 \\
0 \\
\end{array}$ & $\begin{array}{r}98 \\
6 \\
\end{array}$ & $\begin{array}{r}100 \\
6 \\
\end{array}$ \\
\hline 10 & Ganna & 232 & 1080 & 615 & $\rightarrow$ & & Döbrönte & 0 & 79 & 79 \\
\hline 11 & Alsótelekes & 224 & 1063 & $\begin{array}{l}188 \\
400\end{array}$ & $\begin{array}{l}\rightarrow \\
\rightarrow\end{array}$ & 15 & $\begin{array}{l}\text { Szőlősardó } \\
\text { Felsőtelekes }\end{array}$ & $\begin{array}{l}0 \\
0 \\
\end{array}$ & $\begin{array}{r}100 \\
54\end{array}$ & $\begin{array}{r}100 \\
54\end{array}$ \\
\hline 12 & Kupa & 204 & 532 & $\begin{array}{r}196 \\
75 \\
\end{array}$ & $\begin{array}{l}\rightarrow \\
\rightarrow\end{array}$ & 16 & $\begin{array}{l}\text { Tomor } \\
\text { Monaj }\end{array}$ & $\begin{array}{r}37 \\
0\end{array}$ & $\begin{array}{l}63 \\
26 \\
\end{array}$ & $\begin{array}{r}100 \\
26\end{array}$ \\
\hline 13 & Bodrogkeresztúr & 197 & 4297 & $\begin{array}{r}261 \\
460 \\
1398 \\
\end{array}$ & $\begin{array}{l}\rightarrow \\
\rightarrow \\
\rightarrow\end{array}$ & $\begin{array}{l}17 \\
18\end{array}$ & $\begin{array}{l}\text { Zalkod } \\
\text { Szegi } \\
\text { Bodrogkisfalud }\end{array}$ & $\begin{array}{l}0 \\
0 \\
4\end{array}$ & $\begin{array}{r}100 \\
100 \\
77 \\
\end{array}$ & $\begin{array}{r}100 \\
100 \\
81 \\
\end{array}$ \\
\hline
\end{tabular}


A megújuló forrásból származó villamos energia önellátási és exportlehetőségei a magyarországi településeken

(Folytatás.)

\begin{tabular}{|c|c|c|c|c|c|c|c|c|c|c|}
\hline \multicolumn{6}{|c|}{$\begin{array}{c}\text { A HMKE-k és a 0,5 MW alatti kiserőmúvek } \\
\text { összevont teljesítménye alapján }\end{array}$} & \multicolumn{5}{|c|}{$\begin{array}{c}\text { A HMKE-k és a } 0,5 \mathrm{MW} \text { alatti kiserőművek } \\
\text { összevont teljesítménye, valamint } \\
\text { energiaimport alapján a) }\end{array}$} \\
\hline & \multirow[t]{2}{*}{ település } & \multirow{2}{*}{$\begin{array}{l}\text { saját } \\
\text { terme- } \\
\text { lés, \% a) }\end{array}$} & $\begin{array}{c}\text { saját } \\
\text { terme- } \\
\text { lés }\end{array}$ & $\begin{array}{l}\text { energia } \\
\text { export }\end{array}$ & & & \multirow[t]{2}{*}{ település } & $\begin{array}{l}\text { saját } \\
\text { terme- } \\
\text { lés }\end{array}$ & $\begin{array}{l}\text { energia- } \\
\text { import }\end{array}$ & együtt \\
\hline & & & \multicolumn{2}{|c|}{ MWh } & & & & \multicolumn{3}{|c|}{$\%$} \\
\hline \multirow[t]{2}{*}{1} & Egyházasharaszti & 168 & 1189 & 405 & $\rightarrow$ & 19 & Siklósnagyfalu & 2 & 98 & 100 \\
\hline & & & & 76 & $\rightarrow$ & & Old & 0 & 17 & 17 \\
\hline \multirow[t]{2}{*}{15} & Somogyhatvan & 167 & 565 & 197 & $\rightarrow$ & 20 & Visnye & 0 & 100 & 100 \\
\hline & & & & 30 & $\rightarrow$ & & Somogyviszló & 0 & 10 & 10 \\
\hline \multirow[t]{2}{*}{16} & Peterd & 165 & 506 & 120 & $\rightarrow$ & 21 & Pécsdevecser & 14 & 86 & 100 \\
\hline & & & & 80 & $\rightarrow$ & & Lothárd & 0 & 26 & 26 \\
\hline \multirow[t]{2}{*}{17} & Csörötnek & 165 & 1779 & 77 & $\rightarrow$ & 22 & Magyarlak & 91 & 9 & 100 \\
\hline & & & & 622 & $\rightarrow$ & & Vasszentmihály & 0 & 93 & 93 \\
\hline \multirow[t]{3}{*}{18} & Kémes & 156 & 1170 & 93 & $\rightarrow$ & 23 & Drávapiski & 0 & 100 & 100 \\
\hline & & & & 155 & $\rightarrow$ & 24 & Adorjás & 0 & 100 & 100 \\
\hline & & & & 173 & $\rightarrow$ & & Tésenfa & 0 & 94 & 94 \\
\hline 19 & Csomád & 149 & 2956 & 965 & $\rightarrow$ & & Vácrátót & 4 & 24 & 28 \\
\hline 20 & Csonkamindszent & 143 & 289 & 87 & $\rightarrow$ & & Dinnyeberki & 0 & 55 & 55 \\
\hline \multirow[t]{4}{*}{21} & Nógrádkövesd & 142 & 6118 & 611 & $\rightarrow$ & 25 & Legénd & 0 & 100 & 100 \\
\hline & & & & 306 & $\rightarrow$ & 26 & Szécsénke & 0 & 100 & 100 \\
\hline & & & & 852 & $\rightarrow$ & 27 & Szanda & 2 & 98 & 100 \\
\hline & & & & 45 & $\rightarrow$ & & Becske & 0 & 5 & 5 \\
\hline 22 & Hejce & 132 & 628 & 153 & $\rightarrow$ & & Fony & 10 & 31 & 41 \\
\hline \multirow[t]{2}{*}{23} & Buzsák & 127 & 2863 & 472 & $\rightarrow$ & 28 & Táska & 0 & 100 & 100 \\
\hline & & & & 134 & $\rightarrow$ & & Nikla & 1 & 14 & 15 \\
\hline 24 & Pornóapáti & 125 & 975 & 199 & $\rightarrow$ & & Horvátlövő & 1 & 67 & 68 \\
\hline 25 & Hejőpapi & 125 & 2481 & 491 & $\rightarrow$ & & Szakáld & 0 & 70 & 70 \\
\hline \multirow[t]{2}{*}{26} & Zalaszentmihály & 116 & 2070 & 179 & $\rightarrow$ & 29 & Zalaigrice & 0 & 100 & 100 \\
\hline & & & & 106 & $\rightarrow$ & & Nemesszentandrás & 0 & 33 & 33 \\
\hline 27 & Csörög & 112 & 2575 & 280 & $\rightarrow$ & & Vácduka & 4 & 15 & 19 \\
\hline 28 & Bojt & 106 & 605 & 34 & $\rightarrow$ & & Bedő & 0 & 9 & 9 \\
\hline 29 & Nagyhuta & 102 & 240 & 4 & $\rightarrow$ & & Vágáshuta & 63 & 3 & 66 \\
\hline 30 & Demjén & 101 & 1670 & 10 & $\rightarrow$ & & Tófalu & 0 & 1 & 1 \\
\hline
\end{tabular}

a) A villamosenergia-igény százalékában.

\section{Összegzés}

Magyarország 3155 települése közül 2200-ban, a megújuló energiaforrással múködő HMKE-k összesen 4 településen képesek 100\%-ig biztosítani a település éves villamosenergia-igényét. Ez az arány 10 településen 100 és 50\% közötti, 118 településen 50 és $10 \%$ közötti, 1316 településen 10 és 1\% közötti, 752 településen 1\% alatti, míg 955 településen még nem telepítettek ebbe a kategóriába tartozó erőmúvet (7. táblázat). Az eredmények azt mutatják, hogy az 1000 fósnél kisebb települé-

Területi Statisztika, 2020, 60(4): 399-424; DOI: 10.15196/TS600401 
seken a HMKE-k is képesek ellátni a villamosenergia-igényeket, és ez a cél az 1000 és 2000 fő közötti településeken is elérhető közelségbe került. Energiaexporttal további 2 település vonható be, így ez a kategória összesen 6 településen biztosíthatja a 100\%-ban megújuló forrásból az villamosenergia-szolgáltatást.

A megújuló energiát hasznosító, 0,5 MW alatti kiserőmúvek 23 településen képesek biztosítani az éves villamosenergia-igény több mint 100\%-át, továbbá 19 településen ez az arány 100 és 50\% közötti, 52 településen 50 és 10\% közötti, 65 településen 10 és 1\% közötti, 36 településen pedig 1\% alatti, végül 2960 településre 2017 végéig még nem telepítettek ilyen erőmúvet (7. táblázat). A kiserőművek egyértelmúen fedezni tudják a 2000 fősnél kisebb falvak éves villamosenergia-igényét, és ez nem elérhetetlen cél a 10000 fó alatti települések részére sem. A túltermeló települések fel nem használt villamos energiájának átadásával további 20 településen érhető el a megújuló energia 100\%-os aránya, így ez a kategória önmagában 43 települést tehet teljesen zöldáram-használóvá.

A villamosenergia-igényüket helyben elérhető megújuló energiaforrásból ellátó települések száma kiserőmü-kategóriák és ellátási szintek szerint, 2017

Number of settlements supplying their electric energy demand from local renewable sources, by small scale plant-categories and supply level, 2017

\begin{tabular}{c|c|c|c}
\hline \multirow{2}{*}{ Ellátási szint, \% a) } & HMKE-k & $\begin{array}{c}\text { 0,5 MW alatti } \\
\text { kiserőművek }\end{array}$ & $\begin{array}{c}\text { A két erőmú-kategória } \\
\text { összevont }\end{array}$ \\
\cline { 2 - 4 } & \multicolumn{3}{|c}{ teljesítménye alapján } \\
\hline $100-$ & 4 & 23 & 30 \\
$100-50$ & 10 & 19 & 24 \\
$50-10$ & 118 & 52 & 164 \\
$1-10$ & 1316 & 65 & 1301 \\
-1 & 752 & 36 & 699 \\
0 & 955 & 2960 & 937
\end{tabular}

a) Saját termelés a villamosenergia-igény százalékában.

A HMKE és 0,5 MW alatti kiserőmúvek áramtermelő képességének összevonása esetén 30 olyan település van Magyarországon, ahol a két erőmû́-kategóriába tartozó megújuló energiaforrást használó erőművek a település villamosenergia-igényének több mint 100\%-át képesek elóállítani. Ezek az erőművek továbbá 24 településen fedezik a fogyasztás 100-50\%-át, 164 településen az 50-10\%-át, valamint 1301 településen ez az arány 10 és 1\% közötti. Magyarország települései közül 699 esetében ez az arány nem éri el az 1\%-ot, továbbá 937 településen sem a HMKE, sem a 0,5 MW alatti kiserőmú nem létesült (7. táblázat). A két erőmútípus kombinálásával, a 2000 fősnél kisebb települések villamosenergia-igénye jelenleg biztonsággal kielégíthetô, ami középtávon a 10000 fó alatti településméret esetén is megvalósítható. 
A saját villamosenergia-igényüknél többet termelő települések, a fel nem használt villamos energiájuk átadásával további 29 településen biztosíthatják a 100\%-ban megújuló forrásból származó villamos energiát, melyekkel az összevont erőmúkategóriák 59 magyarországi települést tehet teljes mértékben zöldáram-használóvá, ahogyan ez a 3. ábrán a Cserehátban fekvő települések esetében is megfigyelhető.

3. ábra

\section{Alsótelekes, Galvács, Kupa és Gibárt települések villamosenergia-többletének} exportálása a szomszédos településekre, 2017*

The export of overproduced electricity to the neighbouring settlements in the case of Alsótelekes, Galvács, Kupa and Gibárt in the northern part of Borsod-Abaúj-Zemplén county, 2017

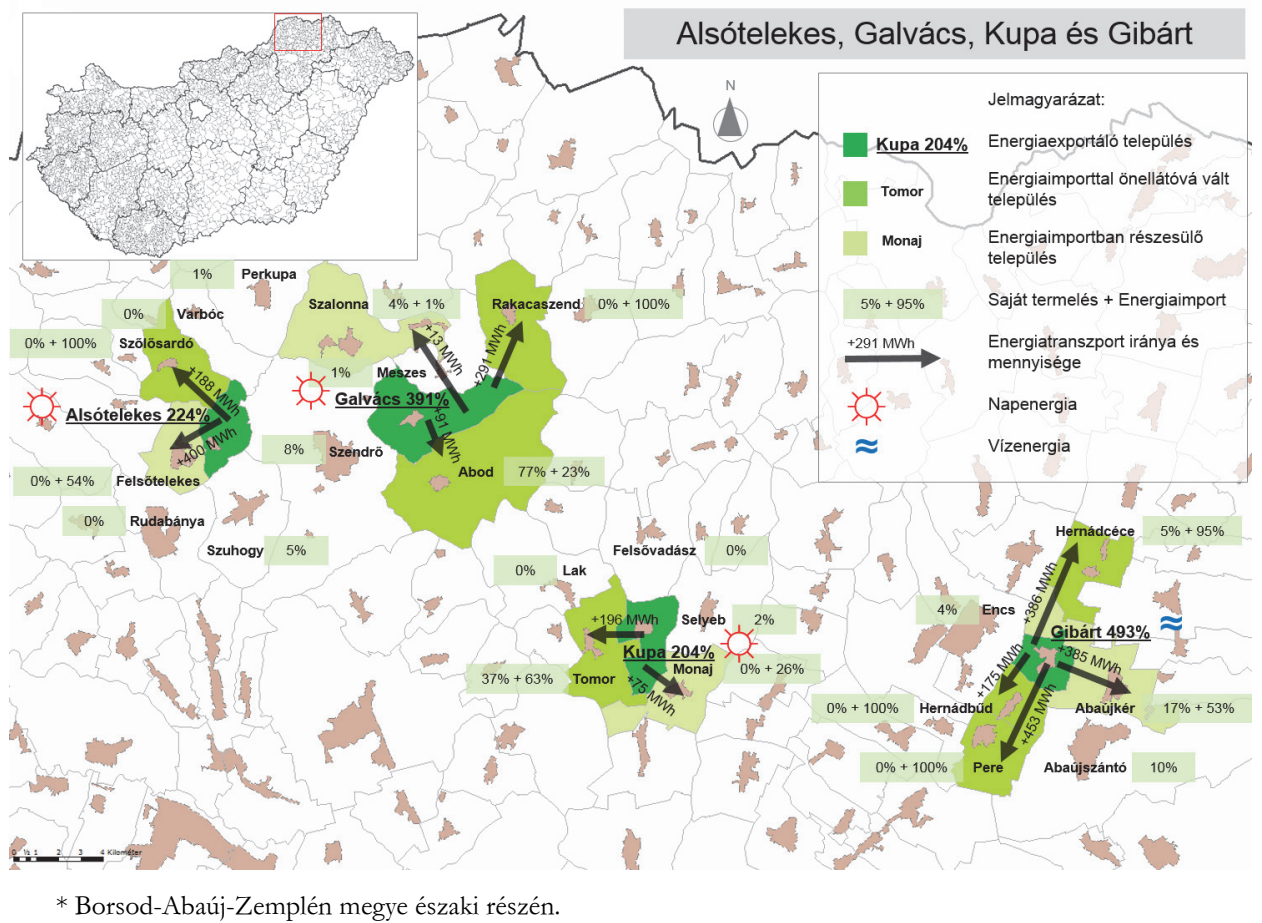

Az eredmények tehát azt mutatják, hogy a decentralizáltan elhelyezkedő, megújuló energiát hasznosító kiserőmúvek már ma is jelentős mennyiségű villamos energiát képesek termelni a település saját területén úgy, hogy a lehetőségek még messze nincsenek kihasználva. A közeljövőben e kiserőmúvek nagy biztonsággal fedezni tudják a 10000 fősnél kisebb lélekszámú magyarországi települések teljes éves villamosenergia-igényét. Ez a magyar településállomány több mint 95\%-a, ami a nagyobb települések felé irányuló energiaátadással tovább növelhető.

Területi Statisztika, 2020, 60(4): 399-424; DOI: 10.15196/TS600401 
$\mathrm{Az}$ ismertetett eredmények mellett el kell ismerni ugyanakkor, hogy e decentralizált települési megújulóenergia-rendszerek kiépítése előtt számtalan akadály (például forráshiány, a közösségi tulajdon és társadalmi együttműködés hiánya) áll ma még Magyarországon (Capellán-Pérez et al. 2020), továbbá az előretekintő gondolkodás alacsony szintje (Baranyai-Varjú 2017), a szabályozási környezet, az energiatárolás és -elosztás technológiai kérdései és a politikai akarat.

A megújuló energiaforrások terjedését jogi szabályozással, gazdasági ösztönzőkkel, oktatással és környezetvédelmi marketinggel hatékonyan lehet gyorsítani, ugyanakkor lassítani is, melyre példa a 2011. évi LXXXV. törvény 2015. január 1-jétől hatályba lépett módosítása (2011. évi LXXXV. törvény), ami a többnyire napenergiát hasznosító HMKE-szegmens 2016. évi növekedésében is erősen megmutatkozott (MEKH 2017). Pedig az egyértelmúen gyors növekedésú HMKE-kategória beruházásait alapvetôen az energiamegtakarítás hajtja, a vonatkozó szabályozás paraméterei és a betáplálási ártámogatás hiánya ellenére.

A jövőbeli lehetőség a szomszédos települések felé irányuló energiatranszport, amikor a túltermelő települések, amolyan kistérségi vagy járási megújuló forrásból villamosenergia-termelő központként elláthatják a szomszédos településeket is (Kulcsár 2015).

Problémát jelent ugyanakkor, hogy Magyarországon a megújuló forrásból termelt és a hálózatba betáplált villamos energia tárolására jelenleg nem állnak rendelkezésre megfelelő és elégséges kapacitások, így azt a hálózaton keresztüli elosztással „tárolják". Ugyanakkor az ország energiafüggőségét növelő, importált villamos energia jelentős részben az energiahiányos időszakokban vásárolt kiegyenlítő energia.

\section{Köszönetnyilvánítás}

A Bolyai János Kutatási Ösztöndíj támogatásával készült.

„Az Innovációs és Technológiai Minisztérium ÚNKP-19-4-DE-36 kódszámú Új Nemzeti Kiválóság Programjának szakmai támogatásával készült."

\section{IRODALOM}

AsHOK, S. (2007): Optimised model for community-based hybrid energy system Renewable Energy 32 (7): 1155-1164. https://doi.org/10.1016/j.renene.2006.04.008

BARANYAI, N.-VArJú, V. (2017): A klímaváltozással kapcsolatos attitűdök területi sajátosságai Területi Statisztika 57 (2): 160-182. https://doi.org/10.15196/TS570203

CAPELlÁN-PÉreZ, I.-JohANisova, N.-YounG, J.-KunZe, C. (2020): Is community energy really non-existent in post-socialist Europe? Examining recent trends in 16 countries Energy Research and Social Science 61: 101348. https://doi.org/10.1016/j.erss.2019.101348

DuiĆ, N.-CARVALHO, M. G. (2004): Increasing renewable energy sources in island energy supply: case study Porto Santo Renewable and Sustainable Energy Reviews 8 (4): 383-399. https://doi.org/10.1016/j.rser.2003.11.004

Területi Statisztika, 2020, 60(4): 399-424; DOI: 10.15196/TS600401 
FLAVIN, C. (1988): Harmadik Világ - Folyik a villamosítás - Kilátásban egy új energiaválság. In: Brown, L. R.-Chandler, W. U.-Flavin, C.: A világ belyzete 1987/88-ban pp. 104-133. Árkádia Kiadó, Budapest.

Goodbody, C.-WALsh, E.-MCDONNELL, K. P.-OwENDE, P. (2013): Regional integration of renewable energy systems in Ireland - The role of hybrid energy systems for small communities International Journal of Electrical Power \& Energy Systems 44 (1): 713-720. https://doi.org/10.1016/j.ijepes.2012.08.012

HaYes, D. (1982): Átmenet a köolaj utáni korszakba Közgazdasági és Jogi Kiadó, Budapest.

KonCZ, G.-NAgyné Demeter, D. (2015): Megújuló energia projektek közösségfejlesztő szerepe Economica 8 (4.2): 142-151.

KulCsÁr, B. (2015): Implementation Opportunities of Geothermal Energy Systems in the Peripheries along the Border of Hungary and Romania Geographica Pannonica 19 (3): 88-100. https://doi.org/10.18421/GP19.03-01

KulCsÁR, B. (2018): Települési villamos energia önellátás meghatározásának módszerei International Journal of Engineering and Management Sciences (IJEMS) 3 (5): 1-15. https://doi.org/10.21791/IJEMS.2018.5.1.

Lovins, B. (1976): Energy Strategy: The road not taken? Foreign Affairs 55 (1): 65-96. https://doi.org/10.2307/20039628

LUND, H. (2006): Large-scale integration of optimal combinations of PV, wind and wawe power into the electricity supply Renewable Energy 31 (4): 503-515. https://doi.org /10.1016/j.renene. 2005.04.008

MÁLEK, J.-REČKA, L.-JANDA, K. (2018): Impact of German Energiewende on transmission lines in the central European region Energy Efficiency 11 (3): 683-700. https://doi.org/10.1007/s12053-017-9594-4

MunKÁCsy, B. (szerk.) (2011): Erre van elöre!: Egy fenntartható energiarendszer keretei Magyarországon Vision 2040 Hungary 1.0. Környezeti Nevelési Hálózat Országos Egyesület, Szigetszentmiklós.

Neves, D.-Silva, C. A.-Connors, S. (2014): Design and implementation of hybrid renewable energy systems on micro-communities: A review on case studies Renewable and Sustainable Energy Reviews 31: 935-946. https://doi.org/10.1016/j.rser.2013.12.047

Rahman, MD. M.-Khan, MD. M.-U.-H.-Ullah, M. A.-Zhang, X.-Kumar, A. (2016): A hybrid renewable energy system for a North American off-grid community Energy 97 (15): 151-160. https://doi.org/10.1016/j.energy.2015.12.105

RAjGOR, G. (2012): Germany grapples with energy plan Renewable Energy Focus 13 (4): 26-29. https://doi.org/10.1016/S1755-0084(12)70084-4

SÁFIÁN, F.-MUNKÁCSY, B. (2015): A decentralizált energiarendszer és a közösségi energiatermelés lehetőségei a településfejlesztésben Magyarországon Földrajz̨i Közlemények 139 (4): 257-272.

SEBESTYÉnNÉ SZÉP, T.-TÓTH, G. (2019): A gazdasági és az energetikai erőterek elmozdulása a világon Területi Statisztika 59 (4): 353-380. https://doi.org/10.15196/TS590401

SøRENSEN, B. E. (1975): A plan is outlined according to which solar and wind energy would supply Denmark's needs by the year 2050 Science 189 (4199): 255-260. https://doi.org/10.1126/science.189.4199.255

Területi Statisztika, 2020, 60(4): 399-424; DOI: 10.15196/TS600401 
Stern, N. (2006): The Economics of Climate Change: The Stern Review Cambridge University Press, Cambridge.

SzupPINGER, P. (2000): Decentralizáció a világ energiarendszereiben Tér és Társadalom 14 (2-3): 173-182. https://doi.org/10.17649/TET.14.2-3.584

UyAR, T. S.-BEŞIKCI, D. (2017): Integration of hydrogen energy systems into renewable energy systems for better design of 100\% renewable energy communities International Journal of Hydrogen Energy 42 (4): 2453-2456. https://doi.org/10.1016/j.ijhydene.2016.09.086

Wen Li, L.-BiRmele, J.-SCHAiCH, H.-KonOLD, W. (2013): Transitioning to Communityowned Renewable Energy: Lessons from Germany Procedia Environmental Sciences 17: 719-728. https://doi.org/10.1016/j.proenv.2013.02.089

\section{INTERNETES FORRÁSOK}

100\% RES COMMUNITIES http://www.100-res-communities.eu/ (100ee Erneuerbare Energie Region)

ALZEY-LAND REGION, 100\% RENEWABLE ENERGY ATLAS https://www.100-percent.org/alzey-land-region-germany/

BiOENERGIEDORF-EFFELTER http://bioenergiedorf-effelter.de/

Bloomberg L. P. NeW EnERgy FinANCE http://www.bloomberg.com/search?query=New+Energy+Finance\&category $=$ Articles

BUNDESMINISTERIUM FÜR WIRTSCHAFT UND ENERGIE: Erneuerbare-Energie-Gesetr EEG 2000-2017 https://www.erneuerbare-energien.de/EE/Redaktion/DE/Dossier/ eeg.html?cms_docId= 401818 (letöltve: 2018. május 15.)

DARDESHEIM RENEWABLE ENERGY PROJECTS, 100\% RENEWABLE ENERGy ATLAS https://www.100-percent.org/dardesheim-germany/

ENERGIAKLUB SZAKPOLITIKAI INTÉZET MÓDSZERTANI KÖZPONT http://www.energiaklub.hu/

ENERGIE REGION, ALLER-LEINE-TAL, 100\% RENEWABLE ENERGY ATLAS https://www.100-percent.org/aller-leine-tal-germany/

European COMmission JoInt Research Centre: Photovoltaic Geographical Information System (PVGIS) https://re.jrc.ec.europa.eu/pvg_tools/en/tools.html

EUROPEAN RENEWABLE ENERGY COUNCIL (EREC): http://www.erec.org/

EUROPEAN RENEWABLE ENERGIES FEDERATION (EREF): http://www.eref-europe.org/

EUROSTAT, SHARE OF ELECTRICITY OF RENEWABLE ENERGY SOURCES IN GROSS ELECTRICITY CONSUMPTION, 2004-2017

https://ec.europa.eu/eurostat/statistics-explained/index.php?title= File:Share_of_electricity_from_renewable_sources_ in_gross_electricity_consumption,_2004-2017_(\%25).png

FWR ENERGIE GENOSSENSCHAFT, GROBBARDORF http://www.grossbardorf.rhoensaale.net/Gemeinschaftsprojekte/Windkraftanlage

Területi Statisztika, 2020, 60(4): 399-424; DOI: 10.15196/TS600401 
German Renewable Energy Association / Bundesverband ERnEuerbare ENERGIE E.V. (BEE) http://www.bee-ev.de/BEE/BEE.php

GO 100\% RENEWABLE ENERGY http://www.go100percent.org/cms/

INSTITUTE FOR LOCAL SELF-RELIANCE (ILSR) https://ilsr.org/community-power-map/ INTERNATIONAL ENERGY AGENCY (IEA) http://www.iea.org/

INTERNATIONAL RENEWABLE ENERGY AGENCY (IRENA) https://www.irena.org/

GÜSSING RENEWABLE ENERGY http:/ /gussingcleanenergy.com/

KSH - KÖZPONTI STATISZTIKAI HIVATAL (2017a): Magyarország közigazgatási helynévkönyve, 2017. január 1. Budapest. https://www.ksh.hu/docs/hun/hnk/hnk_2017.pdf

KSH - KÖZPONTI STATISZTIKAI HIVATAL (2017b): Területi statisztikeai adatok rendszere - TeIR, 2017, Központi Statisztikai Hivatal, Budapest.

https://www.teir.hu/rqdist/main?rq_app=tdm_nd\&rq_proc=main

MAgYAR ENERGETIKAI ÉS KÖZMŰ-SZABÁLYOZÁSI HiVATAL (MEKH) (2018): Összefoglaló a nem engedélyköteles - ezen belül a háztartási méretü - kiserómüvek adatairól (2008-2017) http://www.mekh.hu/download/7/28/60000/nem_engedelykoteles_es_hmke_ beszamolo_2008_2017.pdf

MAgyar VilLAMOSENERgIA-IPARI ÁTVITELI RENDSZERIRÁNYÍTÓ ZRT. - MAVIR (2018): A magyar villamosenergia-rendszer (VER) 2017. évi statisztikeai adatai. Data of the Hungarian electricity system Budapest.

https://www.mavir.hu/documents/10258/154394509/MEKH+MAVIR+ VER+2017_kiadvany_vegleges_20181116.pdf/d345fdb8-7048-4af2-9a63$1 \mathrm{~d} 7415 \mathrm{bb} 84 \mathrm{c} 9$

SIERRA CluB: Ready for 100\% https://www.sierraclub.org/ready-for-100 (letöltve: 2018. május 15.)

SIERRA Club: 100\% Commitments in Cities, Counties, \& States, Ready for 100\%, https://www.sierraclub.org/ready-for-100/commitments (letöltve: 2018. május 15.)

THE GLOBAL 100\%: Renewable Energy Platform http://www.go100re.net/

United Nations (2016): Climate Change Conference Marrakech, Morocco, on 7-18 November 2016. COP22, CMP12, CMA1, Marrakech Vision: World's Most Climate-Vulnerable Countries Aiming For 100 Percent Green Energy, https://unfccc.int/process-and-meetings/conferences/pastconferences/marrakech-climate-change-conference-november-2016/marrakechclimate-change-conference-november-2016

USA ENERGIAÜgYi INFORMÁciós Hivatal (U.S. ENERgy INFORMATiON ADMINISTRATION - EIA): http://www.eia.gov/

WORLD ENERGY COUNCIL: https://www.worldenergy.org/ 100EE ERNEUERBARE ENERGIE REGION

http://www.kommunal-erneuerbar.de/startseite.html

Területi Statisztika, 2020, 60(4): 399-424; DOI: 10.15196/TS600401 


\section{FELHASZNÁLT JOGANYAGOK}

2007. évi LXXXVI. törvény, a villamos energiáról

2011. évi LXXXV. törvény a környezetvédelmi termékdíjról

62/2016. (XII. 28.) NFM rendelet, a megújuló energiaforrásból származó villamos energia termelési támogatás korlátairól és a prémium típusú támogatásra irányuló pályázati eljárásról (NFMR)

63/2016. (XII. 28.) NFM rendelet, a megújuló energiaforrásokból nyert energiával termelt villamos energia múködési támogatásának finanszírozásához szükséges pénzeszköz mértékének megállapítási módjára és megfizetésére vonatkozó részletes szabályokról (finanszírozási rendelet, FINR)

13/2017. (XI. 8.) MEKH rendelet, a megújuló energiaforrásból termelt villamos energia múködési támogatásának mértékéről (MEKHR)

55/2016. (XII. 21.) NFM rendelet, a megújuló energiát termelő berendezések és rendszerek beszerzéséhez és működtetéséhez nyújtott támogatások igénybevételének múszaki követelményeiről (MÚR)

63/2016. (X. 28.) NFM rendelet, a megújuló energiaforrásokból nyert energiával termelt villamos energia múködési támogatásának finanszírozásához szükséges pénzeszköz mértékének megállapítási módjára és megfizetésére vonatkozó részletes szabályokról szóló (Allokációs rendelet)

273/2007. (X. 19.) Korm. rendelet a villamos energiáról szóló 2007. évi LXXXVI. törvény végrehajtásáról

299/2017. (X. 17.) Korm. rendelet, a megújuló energiaforrásból termelt villamos energia kötelező átvételi és prémium típusú támogatásáról (KR)

389/2007. (XII. 23.) Korm. rendelet, a megújuló energiaforrásból vagy hulladékból nyert energiával termelt villamos energia, valamint a kapcsoltan termelt villamos energia kötelező átvételéről és átvételi áráról (KÁT rendelet) 